\title{
Indoor Omnidirectional Antenna Network Planning using Capacity and Coverage Planning in Gandaria 8 Office Tower Building in PT Artisan Wahyu
}

\author{
Fauzi Furqon, Fenny Auliyanti, Rika Mayardi, Haryadi Sarjono
}

\begin{abstract}
Planning to improve the signal condition of cellular telephone networks in a company is very important. PT. Artisan Wahyu is a company engaged in property and real estate. The purpose of this study was to determine the quality and strength of the signal beam at the Gandaria 8 Office Tower using the G-net Track Lite application, to determine the number of indoor omnidirectional antennas based on capacity planning method, and for determining the number of omnidirectional indoor antennas based on coverage planning method. The research method used is quantitative method with a descriptive type of research. By using the analysis method of Capacity Planning and Coverage Planning. Therefore, it is necessary to plan an omnidirectional indoor antenna analysis so that activities in communication can be enjoyed properly. From the results of the research conducted, there were four plans for omnidirectional indoor antenna networks for the 2nd floor based on capacity and coverage of 6 antennas. Whereas for the 22nd floor based on capacity as much as 3 and for coverage as many as five antennas so that the Coverage Planning method is recommended to be applied to the Gandaria Building 8 Office Tower. (FF, FA, RM)
\end{abstract}

Keywords: Capacity Planning, Coverage Planning, LTE Network, Planning Indoor

\section{INTRODUCTION}

\section{$\mathrm{P}$} roviding the best service and facilities is an important task to fulfill for a property and real estate company. PT. Artisan Rev. is a company that manages the Gandaria 8 Office Tower, an office building with a wide range of facilities such as an Omnidirectional Indoor Antenna that facilitates communication in the building. Gandaria 8 Office Tower put at least three antennas on every floor to support the building internal communication.

Revised Manuscript Received on July 10, 2020

* Correspondence Author

Fauzi Furqon, Management Department, BINUS Business School Undergraduate Program, Bina Nusantara University, Jakarta, Indonesia.

Fenny Auliyanti, Management Department, BINUS Business School Undergraduate Program, Bina Nusantara University, Jakarta, Indonesia.

Rika Mayardi, Management Department, BINUS Business School Undergraduate Program, Bina Nusantara University, Jakarta, Indonesia.

Haryadi Sarjono*, Management Department, BINUS Business School Undergraduate Program, Bina Nusantara University, Jakarta, Indonesia. E-mail: haryadi_s@binus.edu

(C) The Authors. Published by Blue Eyes Intelligence Engineering and Sciences Publication (BEIESP). This is an open access article under the CC BY-NC-ND license (http://creativecommons.org/licenses/by-nc-nd/4.0/)
The antennas provided by Building Management is unable to ensure an optimal and stable signal. Many people from building tenants to Building Management complained that they are unable to receive signal in the building, whether it is Low Zone 1-19 or High Zone 20-36. Therefore, a building redesign would be necessary in order to put more antenna on the building. Based on these concerns, the researcher would determine the number of antennas needed to provide the optimal signal in terms of service capacity required by the tenants as well as the numbers of signal coverage to cover the entire area. The amounts of antenna would be determined using two methods of Indoor Network Planning approach, Capacity Planning, and Coverage Planning

\section{A. Problem Formulation}

These are the identified problem formulation based on the background of study:

1. How is the quality of signal at the Gandaria 8 Office Tower?.

2. How to determine the number of omnidirectional indoor antennas based on capacity planning?

3. How to determine the number of omnidirectional indoor antennas based on coverage planning?

\section{B. Literary Review}

1. Effective Capacity

Effective capacity is the capacity or limit set by the company to solve the current operational barriers. (Heizer \& Render, 2015)

\section{Quality}

Quality is one of the essential aspects of a company to become a success in the market. Quality would be acquired when a company manages to deliver customer satisfaction [2]

\section{Antenna}

Antennas are electrical devices that convert electrical signals into electromagnetic waves and then transmit them to free space or vice versa. There two types of antenna that commonly used by the people, Directional antenna and Omni Directional Antenna. [3]

4.Omnidirectional antenna

Omnidirectional Antenna is an antenna which spread its beam/signal to every direction with each direction having the same capacity (wide-beamwidth). [3]

5. Mobile Phone

Mobile phones are digital communication tools.

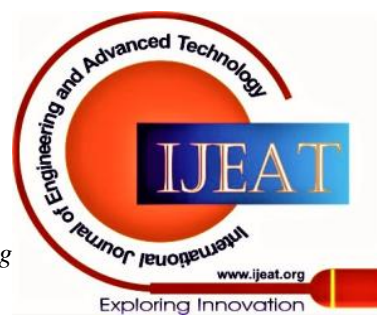


The existence of Mobile phone provides a new way of life for people, especially in communication. Modern people regard the price of the Mobile phone as fair when compared to the value and usage to society. [4]

6. Indoor Network Planning

Indoor coverage includes committed area coverage, necessary traffic capacity, the signal quality that satisfy the customer, and minimal interference. [5]

7. Capacity Planning

Capacity planning is a design method that accounts for the customer's traffic demand. This method requires statistics of population in the target area. The data is needed to predict the number of signal users over the next few years. There are various characteristics of demand traffic for each regional morphological settings. The general steps in conducting capacity planning are: Customer Estimation, Single User Throughput, Network Throughput, and Determine the number of antennas using cell capacity on Capacity Planning. [6]

\section{Coverage Planning}

Coverage planning accounts the gain and loss of a device specification. The propagation model used will also affect the results of radius cell. The first step of coverage planning is to calculate the link budget, which would determine the maximum allowed path loss (MAPL) value between the transmitter and the receiver. Then the researcher would Analyze Building Characteristics, and run a Cost 231 Multiwall to find Cell Area, which would determine the number of antennas based on Coverage Planning. [6]

These are the steps in constructing the directional omni antenna network using the Capacity Planning and Coverage Planning method: (Perpetual, Hafidudin, \& Meylani, 2016)

1. Capacity Planning

$\checkmark$ Calculating Customer Estimation.

Calculating Single User Throughput.

Calculating Network Throughput.

Calculating Cell Capacity.

Calculating the Number of Antennas.

2. Coverage Planning

$\square$ Calculate Link Budget by knowing the value of Maximum Allowed Path Loss (MAPL) Uplink and Downlink.

$\square$ Analyze Building Characteristics.

Calculating Cell Area using the Cost 231 Multiwall propagation model.

Calculating the Number of Antennas.

Based on the above explanations, the researchers draw the conclusion that the omnidirectional antenna network planning approach using the Capacity Planning and Coverage Planning methods is:

1. The walk test results using G-Net Track Lite shows that the quality and strength of the signal beam at the Gandaria 8 Office Tower is not good enough.

2. They need to add four antennas on the 2nd floor and three antennas on the 22nd floor to initiate capacity planning

3. They need to add six antennas on the 2nd floor and five antennas on 22nd floor to start converge planning

\section{RESEARCH METHOD}

\section{A. Research Design}

Research design is the desired research pattern or construct. (Mulyadi, 2012)

Table- I: Research Design

\begin{tabular}{|c|c|c|c|}
\hline \multirow{2}{*}{$\begin{array}{l}\text { Researc } \\
\text { h } \\
\text { Purpose }\end{array}$} & \multicolumn{3}{|l|}{ Research Design } \\
\hline & Research Type & Unit analysis & $\begin{array}{l}\text { Time } \\
\text { Horizon }\end{array}$ \\
\hline $\mathrm{T}-1$ & Descriptive & Organization & $\begin{array}{l}\text { Cross } \\
\text { Sectional }\end{array}$ \\
\hline $\mathrm{T}-2$ & Descriptive & Organization & $\begin{array}{l}\text { Cross } \\
\text { Sectional }\end{array}$ \\
\hline $\mathrm{T}-3$ & Descriptive & Organization & $\begin{array}{l}\text { Cross } \\
\text { Sectional }\end{array}$ \\
\hline
\end{tabular}

Purpose:

T-1: To find out the strength and quality of at the Gandaria 8 Office Tower's signal using G-net Track Lite app.

T-2: To determine the numbers of omnidirectional indoor antennas based on the capacity planning method.

T-3: To determine the numbers of omnidirectional indoor antennas based on coverage planning method.

\section{B. Analysis Method}

The obtained data and the observation results would be processed using the LTE indoor mobile network planning approach using the Capacity Planning and Coverage Planning methods. The Capacity Planning method consists of several plan stages, such as customer estimation, single-user throughput, network throughput, cell capacity, and antenna count. Whereas, Coverage Planning consists of MAPL Link budget calculations, material analysis, cost 231 multiwall, cell area, and total antenna.

As a result, the researcher can conclude that the Office Tower needs to increase the number of antennas on the second floor (Low Zone) and the 22nd floor (High Zone) so that the mobile phone signal in Gandaria 8 Office Tower building could function properly

\section{RESULT AND DISCUSSION}

Based on the analysis, capacity planning needs an estimation of the number of users who will use the network planning results, services that can be accessed by customers, and traffic density in the next few years. Estimated number of users who will use the indoor network could be calculated by maximum user capacity on each floor in the building. Next, the researcher calculates the value of Single User Throughput. The researcher should estimate the traffic \& service model before calculating a single user throughput. Single user throughput calculations are performed to determine the minimum throughput of expected users who access all available services.

The results of this calculation will determine the total value of network throughput. The next step is the estimation of cell capacity.

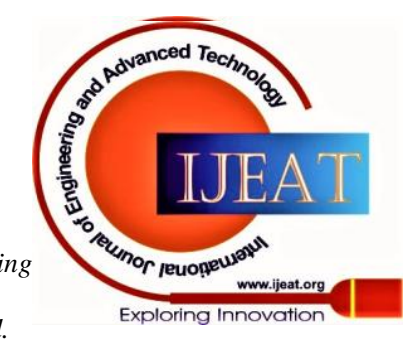


Cell capacity can be interpreted as the maximum capacity of a cell that can be activated. The uplink antenna average throughput and downlink antenna average throughput can determine the number of antennas' estimation based on their capacity.

The number of antennas obtained from the calculation of Capacity Planning is the result of Total Network Throughput to Cell Capacity distribution. Table 1 shows the results of the number of antennas calculation based on Capacity Planning.

Table- II: Estimation for Antenna Capacity

\begin{tabular}{|c|c|c|c|c|c|c|}
\hline \multirow[b]{2}{*}{$\begin{array}{c}\text { Floo } \\
\mathbf{r}\end{array}$} & \multicolumn{2}{|c|}{$\begin{array}{c}\text { Network } \\
\text { Throughput }\end{array}$} & \multicolumn{2}{|c|}{ Cell Capacity } & \multicolumn{2}{|c|}{$\begin{array}{c}\text { Number of } \\
\text { Antennas }\end{array}$} \\
\hline & $\begin{array}{c}\text { Uplin } \\
k\end{array}$ & $\begin{array}{c}\text { Downlin } \\
k\end{array}$ & $\begin{array}{c}\text { Uplin } \\
k\end{array}$ & $\begin{array}{c}\text { Downlin } \\
k\end{array}$ & $\begin{array}{c}\text { Uplin } \\
k\end{array}$ & $\begin{array}{c}\text { Downlin } \\
k\end{array}$ \\
\hline 2 & $\begin{array}{c}4.67 \\
3\end{array}$ & 17643 & 5,8 & 4,8 & 1 & 4 \\
\hline 22 & 3,256 & 12,292 & 5.8 & 4,8 & 1 & 3 \\
\hline
\end{tabular}

Source : Processed company Data 2017

Through capacity planning, floor 2 (Low Zone) get a total of 4 antenna , and floor 22 (High Zone) get a total of 3 antenna.

Coverage Planning is an antenna planning based on the results of the obtained signal coverage. Coverage planning is conducted by accounting materials that have become obstacles. LTE indoor network planning uses $1800 \mathrm{Mhz}$ frequency. Numbers of antenna based on coverage planning are discovered by calculating the MAPL link budget.Through a material analysis, the calculation would use Cost 231 Multi-wall propagation modeling to get the antenna radius numbers based on these equations :

\section{2nd Floor}

$117,5=32,45+20 \log$ FMHZ + $20 \log \mathrm{dkm}+0+[(0,8 \times 16)$ $\left.+(4 \times 6)+(3,4 \times 4)]+2^{\left[\left(\frac{2+2}{2+1}\right)-0,46\right.}\right]_{4,2}$

$117,5=32,45+20 \log (1800)+20 \log \mathrm{dkm}+0+50,4+$ 7,693940438

$117,5=32,45+65,105450+20 \log \mathrm{dkm}+0+50,4+$ 7,693940438

$117,5=20 \log \mathrm{dkm}+155,6493904$

$20 \log \mathrm{dkm}=117,5-155,6493904$

$\log \mathrm{dkm}=-38,1493904 / 20$

$\mathrm{dkm}=10^{-1,90746952}$

$\mathrm{dkm}=0.01237458035 \mathrm{~km}$

$\mathrm{d}=12,3745 \mathrm{~m}$

\section{2nd Floor}

$\mathrm{LT}=\mathrm{LFSL}+\mathrm{LC}+\sum_{\mathrm{i}=1}^{\mathrm{M}}$ nwi Lwi + nf $\left[\frac{\mathrm{nf}\left(\frac{\mathrm{nf}+1}{\mathrm{f}+1}\right)-\mathrm{b}}{\mathrm{Lf}}\right.$

$117,5=20 \log \mathrm{FMHZ}+20 \log \mathrm{dkm}+0+[(0,8 \times 20)+(4 \times 5)$

$\left.+(3,4 \times 4)]+2^{\left[\left(\frac{2+2}{2+1}\right)-0,46\right]}\right]_{4,2}$

$117,5=32,45+20 \log (1800)+20 \log \mathrm{dkm}+0+49,6+$ 7,693940438

$117,5=32,45+65,105450+20 \log \mathrm{dkm}+0+49,6+$ 7,693940438

$117,5=20 \log \mathrm{dkm}+146,8493904$

$20 \log \mathrm{dkm}=117,5-154,8493904$

$\log \mathrm{dkm}=-37,3493904 / 20$

$\mathrm{dkm}=10^{-1.86746952}$

$\mathrm{dkm}=0,01356845754 \mathrm{~km}$ $\mathrm{d}=13,568 \mathrm{~m}$

The equation shows that the indoor antenna radius on the 2nd floor (Low Zone) is $12.6628 \mathrm{~m}$ and on the 22nd floor (High Zone) is $13.568 \mathrm{~m}$. Then, the size of omnidirectional cell antenna is obtained through the calculation below:

2nd floor

$$
\begin{aligned}
\checkmark L & =2,6 \times d^{2} \\
L & =2,6 \times(12,3745)^{2} \\
L & =398,1334507 m^{2}
\end{aligned}
$$

\section{2nd floor}

$\checkmark \mathrm{L}=2,6 \times d^{2}$

$$
\mathrm{L}=2,6 \times(13,568)^{2}
$$$$
\mathrm{L}=478.6356224 \mathrm{~m}^{2}
$$

\section{$\sum$ LTE CELL $=\frac{\text { Luas Area }}{\text { Luas Sel }}$}

Table- III: Antena Coverage Estimation

\begin{tabular}{|l|l|l|l|l|}
\hline Floor & Area & Cell Area & $\begin{array}{l}\text { Total } \\
\text { Antenna }\end{array}$ & \multicolumn{1}{|c|}{$\begin{array}{l}\text { Antenna } \\
\text { Estimates }\end{array}$} \\
\hline $\mathbf{2}$ & 2.126 & 398,1334507 & 5,339918051 & 6 \\
\hline $\mathbf{2 2}$ & 2.126 & 478.6356224 & 4,441792254 & 5 \\
\hline \multicolumn{4}{|c|}{ Source: Company Data processed by Researcher } \\
\hline
\end{tabular}

Based on Coverage Planning, the estimated number of antennas on the 2nd floor (Low Zone) was six antennas, and the estimated number of antennas on the 22nd floor (High Zone) was five antennas.

\section{CONCLUSION AND DISCUSSION}

\section{A. Conclusion}

These are the following conclusions obtained From the results of data processing using the Capacity Planning and Coverage Planning methods:

1. Based on the results of the walk test using G-Net Track Lite, it is known that the quality and strength results of the existing signal beam at the Gandaria 8 Office Tower Building have not given good results.

2. In order o increase the number of antennas based on Capacity Planning, four antennas for the 2nd floor and three antennas for the 22nd floor is needed.

3 . In order to increase the number of antennas based on Coverage Planning, six antennas for the 2nd floor and five antennas for the 22nd floor are needed.

\section{B. Suggestion}

These are several suggestions from the research based on research that has been done by researchers on the omnidirectional indoor antenna network in Gandaria 8 Office Tower to optimize the quality of the signal:

1. The company should pay attention to several important factors before determining a facility so that it could operate properly.

2. The company should apply the Capacity Planning method to determine the number of antennas based on the estimated number of users as anticipation if there is

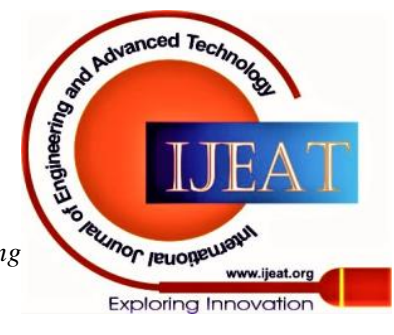


a population increase in the future.

3. The company should apply the coverage planning method to cover the signal in a place that has been observed. Three antennas that have been installed have not been operating correctly

\section{REFERENCES}

1. J. Heizer and B. Render, Manajemen Operasi, 11th ed. Jakarta: Salemba Empat, 2015.

2. H. Sarjono and Natalia, "Servqual Dalam Pelayanan Kelas Pada Laboraturium Manajemen,” Binus Bus. Rev., pp. 404-417, 2017.

3. A. Khozaimi, "Implementasi Jaringan Point To Multipoint Dengan Mikrotik RB 433 Pada Jaringan Internet Asrama Mahasiswa Universitas Trunojoyo Madura," Ilm. Nero, pp. 53-60, 2017.

4. T. F. Tjoe and S. Haryadi, "Model Rantai Markov Pangsa Pasar Operator Selular Di Universitas Bina Nusantara Jakarta Barat," The Winners, pp. 139-154, 2007.

5. M. Siregar, S. A., \& Pinem, "Studi Perencanaan Jaringan Seluler Indoor," Singuda Ensikom, pp. 105-110, 2013.

6. A. T. Permatasari, Hafidudin, and L. Meylani, "Analisis Perencanaan Jaringan LTE - Advanced Menggunakan Metode Fractional Frequency Reuse Dan Fitur Carrier Aggregation Di DKI Jakarta," e-Proceeding Eng., pp. 1937-1947, 2016.

\section{AUTHORS PROFILE}

Fauzi Furqon was born in Jakarta on December 18, 1993. He graduated from Bina Nusantara University on management in 2018. Mr. Fauzi was active in student organizations during his study at Bina Nusantara University.

Fenny Auliyanti was born in Tangerang City on September 16, 1996. She completed her undergraduate education at Bina Nusantara University on management in 2018. Ms. Fenny was active in student organizations during her study at Bina Nusantara University.

Rika Mayardi was born in Pontianak on October 31, 1996. She completed her undergraduate education at Bina Nusantara University on management in 2018. Ms. Rika was active in student organizations during her study at Bina Nusantara University

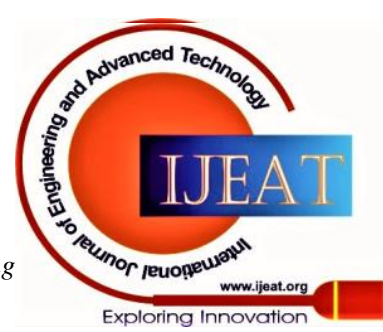

